\title{
AZ ÚJ VÁROSPOLITIKA KORMÁNYZÁSI FILOZÓFIÁJA
}

\section{(Governance Philosophy of the New Urban Policy)}

\author{
PÁLNÉ KOVÁCS ILONA
}

Kulcsszavak:

városi reneszánsz városi tervek városi kormányzás fejlesztéspolitika urban regime

A tanulmány arra kivánja felhivni a figyelmet, hogy a városok felértékelódó szerepe, amely ma már az uniós kohéziós politikában is tetten érhetó, még sok tekintetben nem érvényesül a hazai területfejlesztési intézményrendszerben és a területi közigazgatás modelljében sem. Miközben a fejlesztési források kedvezményezettjeivé egyre inkább hivatalosan is a városok válnak, azok közül is a regionális és metropolisz funkciót betöltö nagyvárosok, helyük az igazgatás rendszerében nem kitüntetett. A másik oldalról viszont a városok térbeli funkciói sem épülnek be szisztematikusan a körzeti szintü szolgáltatások megszervezésének rendszerébe és a tervezésbe sem. Az önkéntes társulások, a kistérségi rendszer és a megyei jogú városi státusz nem nyújt ideális megoldást.

A tanulmány utal arra, hogy nagyobb figyelmet kellene forditani a városi kormányzás új modelljére, filozófiájára, amely az urban regime iskola köruil fogalmazódott meg, de hazai adaptálására még csak nagyon részlegesen került sor.

\section{Az uniós kohéziós politikai fordulat}

Noha a városok soha nem kerültek le a napirendről, hiszen mindig is az érdeklödés középpontjában álltak mind társadalmi, mind gazdasági funkcióikat tekintve, mégis kétségtelenül tapasztalható egyfajta ciklikusság a várospolitikában, városi kormányzásban, mint ahogy a városfejlödésben, urbanizációban is (Enyedi 1988).

A legutóbbi évtized a városok szerepét és különösen kormányzását illetően mindenképpen fontos fordulatot hozott. A policentrikus városfejlesztés, a városi hálózatokra alapozott regionális fejlesztés modellje lényegében nem új Európában. Az egyes országok (különösen Németország, Franciaország, Nagy-Britannia) fejlesztéspolitikája már a hetvenes évtizedben is jórészt ezt a filozófiát követte. A kilencvenes években született európai fejlesztéspolitikai dokumentum, az ESDP, illetve az EU által finanszírozott ESPON program még inkább hangsúlyozta a városi hálózatok térformáló szerepét a fejlesztéspolitikában és a közszolgáltatások megszervezésében.

A városi ,reneszánsz" azonban az uniós fejlesztési politikában jelentősebb hangsúlyt csak az utóbbi években kapott. Nem véletlen, hogy bennünket némileg felkészületlenül ért az a fordulat, amely az uniós kohéziós politikában a városok javára bekövetkezett, ha úgy tetszik, némileg a régiók rovására.

A hangsúly, illetve paradigmaváltás irányítási és egyéb következményeinek a kezelése még az uniós apparátusokon belül is felszültségeket okozott, mint ahogy az 
egyes tagállamok kormányzati szereplöi körében is bizonytalanság forrása volt, hogyan kell beépíteni a városi dimenziót a Strukturális Alapok felhasználási rendjébe. Nem véletlen, hogy a közösségi stratégiai iránymutatások kidolgozását megelözően sokat foglalkoztak azzal, hogyan illeszthető a városok megerősített szerepe a kohéziós politikába (harmadik kohéziós jelentés, az Európai Parlament állásfoglalása a városi dimenzióról a növekedés kapcsán, a Bizottság munkadokumentuma „A kohéziós politika és a városok" címmel, Bristoli kezdeményezés, városok fóruma, tematikus konferencia Barcelonában, ESPON stb.).

Az Európai Bizottság dokumentuma „,A kohéziós politika és a városok: a városok és az agglomerációk hozzájárulása a régiók növekedéséhez és a foglalkoztatottsághoz" címmel (COM 2006, 385) felhívta a figyelmet a városi dimenzió felértékelödésére, és ehhez értelmezési keretet is szolgáltatott a tagállamok számára. Az Európai Parlament és az Európai Tanács ERFA-ról szóló rendelete 8. cikkében kiemeli a városi dimenziókat, hangsúlyozva az integrált stratégiák szükségességét. A bizottsági dokumentum javasolja a tagállamok, régiók és városok partnerségének kiépítését, a városi agglomerációk integrált városfejlesztési stratégiáinak kidolgozását, továbbá, hogy a Strukturális Alapokból nyújtsanak technikai segítséget a városi irányítási hatáskörök kiépítéséhez, modellezéséhez. Külön felhívták a figyelmet arra a lehetőségre, hogy a tagállamok átadhatják a városoknak az operatív programok keretében a fejlesztési programokra szánt források kezelését.

A Régiók Bizottsága egyik véleményében 2006-ban jelezte, hogy a városi dimenzió figyelembe vétele a nemzeti stratégiai referenciakeretekben és az operatív programokban még mindig nem magától értetődő. Ezért is szorgalmazta a régiók bizottsága, hogy a közösségi stratégiai iránymutatások ne csupán a területi sajátosságok keretébe illessze a város dimenziót. Javasolta, hogy az ,irányelvek” vezessen be egy negyedik prioritást, amely a városokra és a városi régiókra koncentrál. Támogatta az Európai Bizottság javaslatát, miszerint a nemzeti kormányok globális támogatás (global grant) nyújtásával és az irányítási feladatok és illetékesség átadásával segítsék a városokat annak érdekében, hogy birtokolják azt a kritikus tömegú forrást és kompetenciát, amely elegendő az új kihívásokra való reagáláshoz. A Régiók Bizottsága arra is felhívta a figyelmet, hogy a városok dimenzióját valamennyi közösségi politikában érvényesíteni kellene. A szociális és civil párbeszédhez hasonlóan területi párbeszédet kezdeményezett a városok új szerepéröl mind európai, mind a tagállamok dimenziójában.

A 2007-2013-ra szóló stratégiai irányelvek a nemzeti regionális támogatásokról végül is nem fogalmazott meg negyedik prioritást, ennek ellenére több helyen is erős hangsúlyokat helyezett el a városi megközelítés érdekében. Már az irányelveket elfogadó tanácsi határozat deklarálja, hogy fontos a kohéziós politika területi dimenziója, az iránymutatásoknak figyelembe kell venniük a városi és a vidéki területek beruházási igényeit. A kohéziós politika területi dimenziója fejezetben külön pontot szentel a városoknak. A városokban végrehajtható programok egyik 
fontos formájaként emeli ki a versenyképesség, például a klaszterekbe rendezés révén megvalósuló fejlesztéseket, másodsorban a leszakadó városi kerületek rehabilitációját, harmadrészt támogatják a városi hálózatképzödést. Az irányelvek is hangsúlyozza, hogy a városi programok végrehajtása ráruházható a városokra, kiemelve az integrált megközelítés szükségességét, jelezve, hogy ezekhez hozzárendelhető új eszköz a JESSICA. A városi reneszánsz tehát lényegében megerősítést nyert az uniós kohéziós politikában is, annak ellenére, hogy erre a felértékelődésre sok tekintetben sem a nemzeti, sem a városi kormányzatok nem készültek fel.

A rendszerváltást követő újraelosztási gyakorlat, a korábbi erősen városcentrikus fejlesztéspolitika kiváltotta ellenszenv hatására, a falusi térségeket helyezte az érdeklődés homlokterébe, az ott keletkezett hátrányok ledolgozását tủzte ki célul. Bár az 1998-ban elfogadott OTK már jelentőségének megfelelő súllyal foglalkozott a városokkal, a tényleges fejlesztéspolitikai irányváltás nem következett be.

Az európai kohéziós politika paradigmaváltása, nevezetesen a versenyképesség, és ezzel összefüggésben a városi fejlesztési központok felértékelődése azonban egyértelmủen új követelményeket támaszt a hazai fejlesztéspolitika formálásával szemben. Az új kihívások különösen az alábbi elemekben jelentek meg, hozzátéve, hogy jórészt inkább rejtve, a második nemzeti fejlesztési terv előkészitése során:

- Kimondatlanul ugyan, de relativizálódik a NUTS2 régiók szerepe, hiszen a versenyképességi célok, illetve a városok térbeli kisugárzó szerepére való hivatkozás alapján már nem kizárólagos földrajzi keretei a beavatkozásoknak. Zavar forrása azonban, hogy a régi földrajzi, tervezési keretek fennmaradtak, míg a városok, mint önálló szereplők nem intézményesített elemei a fejlesztéspolitikának.

- A nemzeti stratégiai referencia keret illetve az operatív programok hagyományos (ágazati és regionális) szerkezete nehezen képes az integrált városfejlesztés szempontjait befogadni. Ez látszik az ÚMFT szerkezetében és prioritásaiban is. Noha megjelentek a városok speciális szempontjai, de még sincs igazán optimális lehetőség integrált városfejlesztési programok megvalósítására még azokban a pólusvárosokban sem, amelyek pedig az érdeklődés homlokterébe kerültek, s lényegében meg is neveződtek a második nemzeti fejlesztési terv prioritásai között.

- A paradigmaváltás „látens” jellege, a rurális térségek nyilvánvaló érdekellentéte miatt a városok és a környezỏ régió kormányzatai között is feszültségek keletkezhetnek, tekintettel a fejlesztéspolitikában keletkezett konkuráló helyzetre. Fontos kérdés, vajon milyen arányokat célszerủ érvényesíteni a központok és a perifériák fejlesztése során, egyáltalán a két prioritás ellentmond-e egymásnak? 


\section{A hazai várospolitika megújulásának potenciális következményei, szükségletei az irányitási rendszerben}

Noha a hazai településhálózat alakulása már önmagban is elegendỏ alap lett volna a felismeréshez, hogy a városok fejlesztése kiemelt feladat, a változás mégis inkább egyrészt a fentiekben említett uniós hangsúlyeltolódásnak, másrészt a közszolgáltatások megszervezését, racionalizálását érintő reformtörekvéseknek köszönhető, amelyek jórészt a többcélú kistérségi társulásokra vonatkozó kormányzati intézkedésekben jelentek meg.

A városokra épüló fejlesztéspolitika nemcsak értékrendbeli, illetve szemléleti változást tesz szükségessé, hanem a fejlesztéspolitikai és önkormányzati, igazgatási intézményrendszer strukturális és múködési reformját is. A jelenlegi közigazgatási és fejlesztéspolitikai intézményrendszer ugyanis elsősorban területi egységekben (kistérségben, régióban), illetve ágazati szemléletü, egyközpontú, hierarchikus irányítási mechanizmusban gondolkodik, miközben a városok nagyobb szerepvállalása, térbeli integráló erejének növelése hálózatos, horizontális irányítási elemeket, eszközöket tenne szükségessé, ha úgy tetszik, a városi dimenzió a magyar központi és területi kormányzási rendszer új filozófiáját igényelné. A városok érdekei ugyanis alulképviseltek, illetve informálisak a jelenlegi irányítási rendszerben. Szükség lenne szisztematikusan végig gondolni minden irányítási szintet és szektort, intézményt, hogyan vezethető át a városi dimenzió a hagyományos struktúrákba. A feladat egyáltalán nem egyszerü, hiszen a területi közigazgatás szervezés mindenütt a világon küzd ezzel a problémával, speciális intézményekkel kísérletezik, tehát aligha vehetők át bevált modellek. Mint e szám más tanulmányai kifejtik, lényegében két fó áramlat létezik, az egyik a várost és környékét szoros intézményesített kapcsolatba füzné, míg a másik a lazább, hálózatos együttmüködési formákat tartja hatékonyabbnak. A törésvonalak végül is a szabályozásba, intézményekbe vetett hit erőssége mentén húzódnak. E megoldások természetesen számtalan konkrét formát öltenek, s hatékonyságuk sokszor nem is a modellválasztástól, hanem a szereplők alkalmasságától, a konkrét földrajzi, társadalmi, gazdasági környezettől fủgg.

A továbbiakban csupán vázlatosan tekintjük át azokat az elemeket, ahol a városok és városhálózatok erősödő szerepét a kormányzás különböző szintjein érvényesíteni kellene, anélkül, hogy bármelyik kérdés részleteibe bocsátkoznánk, hiszen mindegyik dimenzióelem önálló tanulmányt igényelne.

\section{Kormányzati irányítás}

Célszerű lenne a területfejlesztés ágazati irányítását végző minisztériumon belül a városokkal foglalkozó irányítási egység létrehozása, mint ahogy felülvizsgálandó az Országos Területfejlesztési Tanács összetétele is. Vélhetően jót tenne a városi érdekérvényesítési esélyeknek, ha sikerülne egy átfogó városi érdekszövetséget alapítani. Megjegyezzük, a fővárost a kormányzati érdekegyeztetés rendszerébe intéz- 
ményesen be kellene épiteni, amellett, hogy helye a területi közigazgatás rendszerében is végig gondolandó. A városok hatalmi, irányítási struktúrákba illesztése szempontjából fontos lökést adhatna egy kormányzati szintü településhálózati koncepció elfogadása.

\section{Regionális szint}

Az ezen a szinten érvényesíthetó intézkedések nagyrészt a régiók közjogi intézményesítésétól függnek, vajon maradnak-e fejlesztéspolitikai egységek, vagy tovább haladnak a közjogi státusz irányába. A jelenlegi fejlesztési tanácsokban a megyei jogú városokat kivéve a városok képviselete esetleges, hiszen nem szükségszerúen városi polgármester képviseli a kistérségi társulásokat, $\mathrm{s}$ a tanácsi ősszetétel eleve nem tükrözi vissza a régió városszerkezeti sajátosságait. Ennél sokkal fontosabb azonban, ha a régiókban, mint általános politikai és fejlesztéspolitikai egységekben gondolkodunk, hogy a régiót alkotó városok hálózata tárgyává váljon a regionális fejlesztéspolitikának, ennek érdekében célszerú lenne a régió városainak szervezeti összefogása is. A városok közötti szisztematikus együttmüködést alapozhatná meg, ha regionális szinten is készülne városhálózat-fejlesztési stratégia. Különösen fontos a regionális szint esetében a regionális székhely kérdésének rendezése, s ezzel összefüggésben a regionális nagyvárosok speciális jogállásának lehetôsége. Nem lehet a politikai konfliktusok elkerülésére hivatkozva halogatni tovább a régió székhelyének jogszabályban történő kijelölését. Hosszabb távon bizonyára felmerül, hogy az államigazgatás regionalizálása csak akkor hozhatja magával a várt előnyöket, ha a regionalizált szervek székhelyei földrajzilag koncentrálódnak. Ezzel szorosan összefügg a pólus programok kérdése, amelyeket a régiók városfejlesztési és gazdaságfejlesztési elképzeléseivel szorosan össze kellene kapcsolni, különben a pólusok szigetek maradnak, s elmarad a várt szinergikus, illetve agglomeratív hatás. Megjegyezzük, hogy a pólusokra vonatkozó intézkedések beillesztése a nemzeti fejlesztési tervbe, illetve a második NFT rendkívüli módon centralizált irányítási rendszere egyáltalán nem kedvez a regionális nagyvárosok kormányzási kapacitásainak megerősítéséhez, a regionális szerepvállalásra való felkészítés céljának.

A régiók intézményesítése mellett nem lehet megfeledkezni a föváros helyzetéről. Budapest esetében a speciális szabályozás kényszere többszörösen is adott volt: fövárosi rangját az alkotmány garantálja, gazdasági, politikai súlyát a mérete biztosítja, térbeli tagoltsága, agglomerációja pedig egyenesen szükségessé teszi.

A törvényhozó gyengítette a föváros kormányzásának hatékonyságát azzal, hogy a kerületeknek szinte korlátlan önkormányzati autonómiát adott. A föváros esetében is az alulról építkezés, a bázishoz való közelség koncepciója, értékrendje érvényesült (hasonlóan a teljes rendszer felépítéséhez), s ezzel óhatatlanul gyengült a föváros ,akcióegysége”. A megosztott, kétszintủ modell tehát eleve a kooperáció kényszerére alapozott, magában hordozva a konfliktusokat, ami végül is 1994-ben bizonyos korrekciókhoz vezetett a fövárosi szint megerösítésének szándékával. Azzal azonban, hogy a kerületek és a fövárosi szint közötti viszonyrendszer alapjaiban 
továbbra sem hierarchikus (bár hordoz magában föderatív és centralista elemeket is), fennmaradtak a kétszintüséggel, a decentralizáltsággal együtt járó koordinációs problémák, a kerületekkel való egyeztetés kényszere, a kerületi „ellenállás” különbözö eszközei stb.

A fővárosi agglomerációval való viszonyrendszer a felaprózottságot tovább növeli (Perger 1999). A közjogi együttmüködés számára lényegében az önkéntes társulási rendszer áll rendelkezésre, továbbá a fejlesztéspolitikában az agglomerációs fejlesztési tanács. Kérdés, hogy a közigazgatási és fejlesztéspolitikai rendszer egymásra lapolódása, földrajzi inkonzisztenciája mennyiben segíti vagy éppen gátolja az egyetlen magyar metropolisz-térség versenyképességét.

A megyei szinttel kapcsolatban fejlesztéspolitikai szempontból alapvető aggály, hogy lényegében ezen a szinten már csak intézmény van, tényleges tevékenység viszont nincs, hiszen a megyei fejlesztési tanácsok jószerével nem rendelkeznek már forrásokkal. A gond forrása persze az, hogy miután a megyei fejlesztési tanácsokat maga az Ötv. hozta létre, a megszüntetésük is kétharmados többséget igényelne. Még fontosabb azonban a megyei jogú városokra vonatkozó közjogi szabályozás kérdése. Az esetlegesen létrejövő regionális önkormányzatokkal szemben nyilvánvalóan kevésbé lesz relevanciájuk, a regionális érdekérvényesítési rendszerben a helyük választási szempontból is végig gondolandó. Kérdés, hogy mi legyen a megyével való viszonyrendszerük, mégpedig két opciót végig gondolva, ha megszünnének a megyei önkormányzatok, illetve, ha nem. Annyi bizonyos, hogy a képviseleti szétválasztottság nem tartható fenn, ugyanakkor a megyeszékhely (tehát nem regionális) nagyvárosok különleges státuszát valamilyen formában célszerü megörizni, nem csupán lélektani okokból, hanem a városi területi ellátó szerepkör intézményesítése okán.

A megyei jogú városokra vonatkozó szabályozás, követve a korábbi hagyományokat, privilegizált státuszt jelent, erre utal az is, hogy az önkormányzati törvény önálló fejezetet szentel nekik. A szúkszavú fejezet szabályaiból arra kell következtetni, hogy a törvényhozó alapvetően a városok méretét, pontosabban népességszámát tartja relevánsnak, amely szükségessé teheti a belsô szervezet tagolását. A szabályozásnak sajátos módon nem az a lényege, hogy bizonyos nagyságrend felett a városok speciális kezelést igényelnek az ellátott feladatok okán. A magyar szabályozás logikája nem a méret kezelése, sokkal inkább a megyei önkormányzatoktól való függetlenség biztosítása volt azzal, hogy a megyei jogú városok saját területükön felhatalmazást kaptak az egyébként a megyék hatáskörébe utalt feladatok ellátására. A megyei jogú városokat választójogi szempontból is kihasították a megye testéből, a megyei jogú városok nem küldenek képviselöket a megyei testületbe. A választott modell tehát csak felerősítette azt a kétségtelen feszültséget, ami a nagyvárosok és a körülöttük lévő területi szintü önkormányzati egységek között már szociológiai, közgazdasági értelemben is gyakran megjelenik. Nem csoda tehát, hogy a kilencvenes évek elején a megyei és megyei jogú városok önkormányzatai közötti viszonyrendszert a teljes elzárkózás jellemezte. A megyei és a megyei jogú városi önkormányzat közötti elszigeteltséget nem oldotta meg 1994-ben az önkormányzati törvény módosí- 
tása sem, amely a két önkormányzatot indirekt módon együttmúködésre kötelezte az ún. egyeztetó bizottság létrehozásával, hiszen e bizottságok tényleges „egyeztetö” funkcióiról nem történik még említés sem a törvényben.

A megyei jogállás nem azt szolgálja, hogy a nagyváros és a környéke a körzeti szolgáltatások szempontjából egységet alkosson, vagy, hogy nagyobb mérete folytán összetettebb belső szervezeti, képviseleti rendszere legyen, sokkal inkább azt, hogy a nagyváros ne szoruljon a megyei szolgáltatások igénybevételére. Ez a meröben eltérő szabályozási logika, társulva a megyei jogú városok kétségtelenül megjelent önellátási törekvéseivel, sajátos párhuzamosságokhoz vezetett a nagyvárosi térségek közszolgáltatási rendszerében, tovább szaporítva a magyar önkormányzati rendszer középszintjének strukturálisan megoldandó problémáit.

Ugyanakkor azt is tudni kell, hogy a megyei jogú városok a rendszerváltást követô önkormányzati rendszer jelentős sikereit is produkálták, már ami az újításokat, a múködés professzionalizmusát illeti. Csak sajnálni lehet azoknak az előnyöknek az elmaradását, amelyeket a megyei és megyei jogú városi önkormányzatok valóságos együttmüködése eredményezhetett volna.

A kistérségi szint tekintetében, véleményünk szerint jelentős változásokra lenne szükség, amennyiben a városhálózati szempontokat tekintjük alapvető fontosságúnak. Alapvetó gond, hogy a 175 kistérség településszerkezeti szempontból rendkívül különböző, a városok száma, szerepe, struktúrája vonatkozásában is. Nehéz ugyanolyan igazgatásszervezési és döntési mechanizmusokat müködtetni az alig néhány, illetve a több tucatnyi települést magában foglaló egységekben. Azokban a kistérségekben, ahol több városi központ van, törekedni kell a centrumképzésre (ez még nem akadálya bizonyos funkciók megosztásának). A kistérség, mint közigazgatási egység, székhely kell, hogy koncentrálja a társulás és az államigazgatás központi intézményeit. Ugyanakkor a társulási döntési mechanizmusban óhatatlanul fontos a városi szociológiai „fölény” ellensúlyozása, ugyanúgy, mint a kistelepủlések számbeli fölényével járó hatalmi aszimmetria kezelése, egyben az operativitás biztosítása is. A közjog egyik komoly szakmai adóssága, hogy megoldja a város és környéke együttmủködésének problémáját abban az esetben, amikor nincs egy felettes önkormányzati szint, hanem a társulási formával igyekeznek a koordinációt megoldani. Nagyon fontos lesz a kistérségi társulási jog aszerinti differenciálása is, amit a székhely városok mérete, vagy a kistérség településszerkezete alapoz meg. Másként múködik az urbánus, az agglomerációs, a metropolisz és a rurális, az egyközpontú és a policentrikus kistérség.

\section{Városok nemzeti és nemzetközi hálózatai}

A városok szerepének kutatásában rendkívüli érdeklődés tapasztalható a nemzetköziesedés iránt, melyet európaizációnak, glokalizációnak is szokás nevezni (Lefévre 2007). E kérdéskörnek csupán irányítási konzekvenciáira utalva, a várospolitika innovativitása erōsen függhet attól, hogy a városok milyen módon szervezik meg önmagukat, egymással milyen hazai és nemzetközi kapcsolatrendszereket 
építenek ki. A már említett országos városszövetség megszervezésének szükségessége mellett utalunk a tematikus városhálózatok fontosságára. Európában a városi reneszánsz egyik megnyilvánulási formája, hogy a városok, a városi polgármesterek nagyon sok fontos gazdasági, társadalmi, politikai, környezeti kérdés mentén összefognak nemzetközi és nemzeti hálózatokat alkotva. Ezekben a magyar városok is részt vesznek, de a tapasztalatok, a kapcsolati tőke egyelöre nem hasznosul kellő mértékben. Különösen fontos lenne például a pólusvárosok összefogása, de számtalan tematika ad lehetőséget arra, hogy a várospolitikusok sokkal aktívabb résztvevői legyenek a nemzeti és nemzetközi szakmai közéletnek, és ezek a hálózatok tovább adják a legjobb gyakorlatokat stb.

\section{Körzeti szolgáltatások szintje}

Miközben a városok a helyi közszolgáltatások megszervezésének domináns terei, mégsem állithatjuk, hogy a szolgáltatások városi határokon túli igénybe vételének kérdései közjogi és finanszírozási szempontból rendezettek lennének. A strukturális, intézményi kérdések mellett a városfejlesztés, városüzemeltetés számtalan dimenziója igényelne szakmai elemzéseket, speciális szabályokat, finanszírozási mechanizmusokat. Különösen izgalmas a spillover hatások megjelenése a finanszírozási rendszerben, a magántöke bevonása a városfejlesztésbe, üzemeltetésbe, a városfejlesztés nemzeti finanszírozása stb.

A várossá nyilvánítás, a városi státusz birtoklása közjogilag alig jelent különbséget a települési önkormányzatok között. Az önkormányzati törvény ugyan megkülönbözteti elnevezésében a községet, várost, a fơvárost és kerületeit (ezeket tekinti települési önkormányzatnak a $6 \S(1)$ bekezdés, holott nyilvánvalóan a megyei jogú város és a nagyközség is önálló kategória), de a későbbi rendelkezések során jórészt megfeledkezik erről. Abban a fejezetben például, ahol a területszervezés alapjait tárgyalja, s a címben a községről, városról és területükről szól, érdekes módon nem rendezi a várossá nyilvánítás feltételeit, például annak minimális népességszámát sem (miközben a községeknél ez megtörtént 1994-ben). De e formai következetlenségek eltörpülnek ahhoz képest, hogy a városok közjogilag lényegében nem kaptak általános felhatalmazást többlet vagy körzeti feladatok ellátására, az önkormányzati törvény ugyanis pusztán nagyobb és kisebb népességszámú települési önkormányzatok esetében jelzi a hatásköri differenciálás elvi lehetőségét.

\section{Városok a tervezési rendszerben}

Jelenleg a területi tervezés szintekben gondolkodik, nem kezeli a városi körzeteket, s különösen nem a nagyvárosok helyzetét. A tervezés közjogi megalapozása részeként (nagyon fontos lenne, hogy erre valóban sor kerüljön) elemezni szükséges, hogyan kapcsolhatók össze a városi és a környéki tervek, mi legyen a városi tervek kötelező tartalma, hogyan illeszkednek a városi tervek a tervhierarchiába, milyen módon kapcsolandó össze a tervezés szintjén a városok és környékük stb. 
Összegezve hangsúlyozni szeretnénk, hogy a fenti kérdésfelvetések csupán arra szolgáltak, hogy felhívjuk a figyelmet arra, a városi dimenzió újragondolása lényegében a városok irányítási környezetének az elemzését, újraszabályozását igényelné. Elemzések, modellek sokasága mutat rá arra az igazságra, hogy az urbánus terek számára sem létezik azonban egyetlen alkalmas múködési, szervezeti modell. A városi, különösen a nagyvárosi kormányzás szociológiai, igazgatás és politikatudományi kutatásokkal feltárt jelenségei erős kontrasztot mutatnak a hagyományos nemzetállami, képviseleti, illetve önkormányzati közjogi modell sajátosságaival. A disszonancia azért figyelmeztető, mert a modern társadalom és gazdaság olyan problémái is ebben a térben jelennek meg koncentráltan, amelyekre a kormányzati szint nem képes hatékonyan reagálni. Ugyanakkor a városokban felhalmozódott problémák helyi megoldása sok esetben akadályokba ütközik: „A város többé nem az a tér, amelyik a megoldást kínálja, sokkal inkább olyan aréna, ahol a megoldást meg kell találni." (Kearns-Paddison 2000, 849) A városok reneszánsza tehát akkor eredményezhet pozitív elmozdulást a legújabb kihívásokra válaszolva, ha a többszintú kormányzás rendszerében adekvát hely, státusz, eszköz- és intézményrendszer jelölhető ki a számukra.

Emellett, természetesen ugyanolyan fontos, hogy a városok belső kormányzása maga is alkalmassá váljon a megváltozott szerep gyakorlására.

\section{A városi kormányzás, politológiai szempontok}

A nemzetközi szakirodalom az utóbbi évtizedekben rámutatott arra, hogy a városi kormányzás lassan kinövi a klasszikus önkormányzati, képviseleti modellt, ami szükségessé teszi a hagyományos közjogi döntési mechanizmusok újraszabályozásának megindítását. Nem csak arról van szó, hogy a képviseleti demokrácia hagyományos értékei, intézményei általában is átalakulva nyilvánvalóan az önkormányzati rendszert is érintik, hanem arról, hogy a városok kormányzásában egyszerre kell belső és külső, a városfalakon kívüli szereplök együttmúködését megszervezni.

Amíg a 20. század második harmadában a vidékről elvándorolt népesség miatt elsôsorban a kistelepülések igazgatási problémáira kerestek megoldást, addig az utóbbi időszak jellegzetessége, hogy a városi terekben válik szükségessé a korábbitól eltéró irányitási modell. Az urbanizáció általában is a városok felelősségét és jelentőségét növelte, hiszen a szolgáltatások nagyobb részét a városokban kell megszervezni a vidéki népesség számára is. A helyi kormányzás nagyobb hatékonysága és demokratikusabb megszervezése sem tekinthető új követelménynek. A „városi reneszánsz" a tradicionális területi közigazgatás-szervezést mégis több szempontból új kihívások elé állitotta. A városok gazdaságát, infrastruktúráját és társadalmát érő változások gyorsasága drasztikusan nőtt, a változásokra adandó válaszokban alapvetővé vált a helyi kormányzatok szerepvállalása, $\mathrm{s}$ a hatékonysági és demokratikus követelmények szinergiảja igazán csak az utóbbi időben ígér előnyöket (Hambleton et al 2003, 149). 
A professzionális városmenedzsment, az új kommunikációs technológiák használata, a demokratikusabb részvétel rugalmas, hatékony formáinak bevezetése módszerbeli, értékrendszerbeli, belső szervezeti változásokat igényel. Ugyanakkor a városi kormányzás a területi közigazgatás-szervezés strukturális rendjére is jelentős változásokat kényszerít. A globalizáció, a világméretü gazdasági verseny a nagyvárosok szerepét értékelte fel, amelyek a termelés döntö színterei, a versenyképesség erösítésének fontos szereplői, melyek mára nagyobb, összefüggő térségek, agglomerációk, metropolisz régiók központjaivá váltak. Az utóbbi évtized egyik legintenzívebb kutatási területe volt a városok kormányzása a hatalmi értelemben policentrikus térben és a sokszereplős, plurális intézményrendszerben.

Kétségtelen, hogy szinte mindig jelentkezik valamilyen módon a demokratikus deficit problémája nem csak a közvetlen állampolgári részvétel korlátozottsága, hanem az agglomerációban müködő önkormányzatok és a nagyváros közötti kapcsolatrendszer viszonylatában is. A városi kormányzatok méretének növekedése, összetetté válása miatt vált feladattá a városon belüli decentralizáció, a demokratikus részvétel különböző formáinak a kialakítása (kerületek, részönkormányzatok, bázisközösségek, szomszédságok stb.).

A helyi kormányzatokat elemzö kutatások már a hetvenes években rámutattak arra, hogy a helyi igazgatás bürokratikus kötöttségei egyre kevésbé alkalmasak a gazdasági környezettel való kapcsolattartásra, az új kihívásokhoz való alkalmazkodásra. A helyi gazdasági koordinációnak két fajtája a centrális, amikor az önkormányzat egyedüli generálója a folyamatoknak, illetve a résztvevők kölcsönös alkalmazkodására épülő horizontális koordináció (Rückwardt 1978). E két típus közül az utóbbi életképesebb, de a helyi kormányzatok müködési mechanizmusainak, eszközeinek jelentős átalakítását igényli. Ezért hívják fel a figyelmet arra, hogy a múködési módszereket és formákat, intézményeket a megváltozott körülményekhez kell igazítani, a helyi politika egyes szektoraiban sokszínủ kapcsolattartási formáknak kell kialakulnia (Stoker 2000).

A gazdasági folyamatok globalizálódása, a városok közötti verseny megjelenése a gazdasági szereplőkkel való viszonyrendszert új dimenzióba helyezte. Az új kihívásokra adott helyi válaszok gyakran problémákat, konfliktusokat idéznek elö a hagyományos kormányzati szerkezetben. A gazdasági és önkormányzati szereplök közvetlen konzultációja gyakran kizárja a nyilvánosságot, a közvetlenül választott demokratikus fórumok szerepét az elődöntések szentesítésére korlátozza. Németországban például már régóta vita folyik arról, hogy az egyre terjeszkedő ún. inszcenált, megrendezetett korporatizmus demokratikus legitimitása hiányzik, $\mathrm{s}$ "veszélyt" jelenthet a helyi demokrácia intézményrendszerére (Heinze-Volezkow 1991). Az Egyesült Királyságban a public-private szerveződések (városfejlesztéssel, továbbképzéssel foglalkozó korporációk) pedig jelentős mértékben központi kormányzati ellenörzés mellett múködtek, éppen a helyi önkormányzatok kiszoritásának eszközeként (Duncan-Goodwin 1988; Lewis 1992). A politika, illetve az igazgatás legfrissebb jelensége, a hálózatosodás sem nyújt „elegendő demokráciát”, 
annak ellenére, hogy kétségtelenül csökkenti a helyi és regionális kapcsolatrendszerek fragmentáltságát (Amin-Thrift 1995).

$\mathrm{Az}$ ún. urban regime elmélete, kutatási irányzata azt az új szituációt ismeri fel, amelyet a globalizálódó körülmények között a városok fejlesztési forrásokért, befektetőkért folytatott versenye jellemez. Ezért helyezi érdeklődésének fókuszába a helyi gazdaságfejlesztés és a helyi politikai viszonyok új összefüggésrendszerét. Az urban regime elmélet az 1980-as évektől jelenik meg az USA-ban, és még korántsem rendelkezik olyan elméleti és módszertani stabilitással, olyan jelentős empirikus kutatási eredményekkel, mint a korábbi elitista és pluralista iskolák (Stoker 1995). Noha jelentős mértékben támaszkodik a korábbi kutatási elözményekre, ennek az elméletnek egyik megkülönböztetö vonása, hogy erősen fókuszál a helyi kormányzati és nem kormányzati szektor kölcsönös függőségére, és a városi új kihívásokra adható válaszok széles skáláját regisztrálja. A korábbi marxista, neomarxista felfogásokkal ellentétben, amelyek a gazdaság determinista felfogását képviselték, azt vallja, hogy a helyi kormányzás mégis rendelkezik bizonyos relatív autonómiával. A hagyományos politikai intézmények azonban már nem képesek adekvát válaszokra, $\mathrm{s}$ a várospolitika fontos csoportjainak érdekeit figyelmen kívül hagyják. Különösen az üzleti szektor szerepét emelik ki, amelyik ugyanakkor korlátozza a demokratikus intézmények müködését. A közvetlen elözményként értékelhető ,growth machine" elmélettől eltéröen a gazdasági szektor szerepét az „urban regime" iskola nem értékeli túl, hiszen azok szerepe markánsan inkább a sikeres, növekedő városokban és szituációkban mutatható ki (Clark 2003). Az urban regime elmélet elutasítja az ún. hiperpluralisták pesszimista véleményét is, miszerint a városok kormányzása olyan mértékben vált fragmentálttá, hogy a helyi kormányzatok már nem is képesek azt uralni. Az elmélet egyik legmarkánsabb képviselóje, Stone szerint a városi kormányzás intézmények és szereplök rendkívül komplex, megosztott hálózata, amelyből hiányzik a konszenzus. A hatékony kormányzás feltétele, hogy az önmagában korlátozott kapacitású helyi önkormányzat segítségével a nem kormányzati szereplök viszonylag stabil informális csoportja hozzáfér az intézményi forrásokhoz, melyek alapján befolyása fenntartható a helyi döntéshozásban. Az új kérdésfeltevés nem az, kié a hatalom, ki képes érvényesíteni az érdekét, hanem, hogy hogyan lehet a kapacitásokat egyesíteni a közös érdekek megvalósításáért (Stoker 1995). Ahogy Stone szellemesen megfogalmazta, meg kell különböztetni a valami fölött gyakorolt hatalmat a valamiért gyakorolt hatalomtól (power „over" - power „to") (Stone 1989, 229). Az elmélet nem tulajdonít a választott képviseletnek elsődleges jelentőséget, s nem állítja, hogy mindenki egyenlö hatalommal, partnerként vesz részt a döntéshozásban. A hálózaton belüli pozíció különösen a társadalmi tranzakciók stratégiai ismerete és az ennek megfelelö cselekvéshez szükséges kapacitás, továbbá a források feletti kontroll lehetőségén múlik. A figyelem elsősorban nem a szereplökre, hanem a koalícióképződés mechanizmusára irányul, illetve az eredményességre, $\mathrm{s}$ nem arra, hogy azzal a nyilvánosság mennyire ért egyet. A célok kitüzése, a koalíció létrehozása arra figyel, mi az, ami végrehajtható, és kik azok, akik a leginkább képesek elősegíteni az eredményt. 
Minél nagyobb településról van szó, annál inkább van esélye azonban egyéb szereplöknek is a hálózatba kapcsolódásra. Stone szerint a városi politika minőségét a kormányzó koalíciók összetétele, a koalíción belüli kapcsolatok és a tagok által kontrollált források mennyisége, minősége szabja meg (Stone 1993).

Magyarországon a települések többségében a civil társadalom fejletlen, a gazdasági szervezetek ereje differenciált, területileg is rendkívül egyenetlenül oszlanak meg, ezért feltételezhetö, hogy a hálózatokban sem képesek erős, tartós pozíciót szerezni. Ez nem jelenti a hálózatok hiányát, sem azt, hogy a hálózatokban nem vesznek részt helyi civil és gazdasági, üzleti szereplök. Pusztán azt, hogy ezeknek a pontoknak az együttmúködése, kapcsolatrendszere nem a kölcsönös, illetve közös érdekek érvényesítésére törekszik. Éppen ebben a vonatkozásban feltételezhető jelentős eltérés az „ideáltipikus” kormányzási, hálózati modelltől. Ez utóbbi ugyanis nem egyéni érdekeket érvényesítô, alkalmi szövetkezést jelent, hanem a városi környezettel szembeni tudatos, hosszú távú stratégia követését (amibe beleértendő a kirekesztés és a bevonás is), tudatos kislépések megtervezését, a végrehajthatóság képviseletét az értékpreferenciák helyett, a sikerességet az absztrakt nyilvánosság, közösségi támogatottság helyett (Stone 1993). E modellnek nem az a lényege, hogy valamifajta elit kiválasztódik és kormányoz, hanem az, hogy kialakulnak és fenntarthatóak a tartós és szabályozott partnerség feltételei.

Nálunk ez a fajta, pragmatikus, siker illetve eredményorientált helyi közpolitikai modell még inkább kivétel, mint szabály, $\mathrm{s}$ ha érvényesült is esetenként, az feltételezhető, hogy inkább a külsö körülmények sikeres összjátékának, semmint a helyi politikusok tudatos modellválasztásának köszönhető. A helyi kormányzás arénája szereplöit és mechanizmusait tekintve vélhetően szegényesebb, amely nem közelít sem a hatalompolitikai (legitimáció, támogatottság, nyitottság), sem a közpolitikai (sikeresség, eredményesség, szakszerüség) optimumhoz, alapvetön a közszektor dominanciáját mutatja anélkül, hogy a közhatalmi eszközök önmagukban eredményes kormányzást alapozhatnának meg.

Magyarországon a városi kormányzás még alig kutatott terület (Kákai 1996; 2004; Kunszt 2001; Soós 2004), holott számtalan jelenség utal arra, hogy az urban regime elméletben felvetett problémák nálunk is megjelentek. Szükséges lenne tehát az önkormányzati döntési rendszer továbbfejlesztési alternatíváit kidolgozni.

\section{Irodalom}

Amin, A.-Thrift, N. (1995) Institutional issues for the European regions: from markets and plans to socioeconomics and powers of association. - Economy and Society. 1.41-66. o.

Clark, T.N. (2003) Globalisation and Transformation in Political Cultures. - Hambleton, R.-Savitch, H.Stewart, M. (eds.) Globalism and Local Democracy. Challenge and Change in Europe and North America. Palgrave Macmillan, Houndmills. 67-91. o.

COM (2006) A bizottság közleménye a tanácsnak és az Európai Parlamentnek. Kohéziós politika és a városok: a városok és az agglomerációk hozzájárulása a régiók növekedéséhez és a foglalkoztatottsághoz. http://ec.europa.eu/regional_policy/consultation/urban/com_2006_0385_hu.pdf

Duncan, S.S.-Goodwin, M. (1988) The Local State and Uneven Development: Behind the Local Government Crisis. Policy Press, Cambridge. 
Enyedi Gy. (1988) A városnövekedés szakaszai. Akadémiai Kiadó, Budapest.

Hambleton, R.-Savitch, H.-Stewart, M. (eds.) (2003) Globalism and Local Democracy. Challenge and Change in Europe and North America. Palgrave Macmillan, Houndmills.

Heinze, R.-Volezkow, H. (1991) Kommunalpolitik und Verbände. Inszenierter Korporatismus auf lokaler und regionaler Ebene. - Heinelt, H.-Wollmann, H. (Hrsg.) Brennpunkt Stadt. Birkhauser Verlag, Basel, Boston, Berlin. 187-206. o.

Judd, D. (2000) Strong Leadership. - Urban Studies. 5-6. 951-963. o.

Kákai L. (1996) Egy nagyvárosi önkormányzat müködési mechanizmusai. - Horváth M.-Kiss J. (szerk.) Aréna és otthon. Politikai Tanulmányok Intézete Alapítvány, Budapest. 277-331. o.

Kákai L. (2004) Önkormányzunk értetek, de nélkületek. Századvég, Budapest.

Kearns, A.-Paddison, R. (2000) New Challenges for Urban Governance: Introduction to the Review Issue. - Urban Studies. 5-6.845-851. o.

Kunszt M. (szerk.) (2001) Politikum Pécsett. PTE BTK Politikai Tanulmányok Tanszék, Pécs.

Lefévre, C-d'A.E. (2007) Why cities are looking abroad and how they go about it. - Environmnetal and Planning C. Government and Policy. 3. 317-327. o.

Lewis, N. (1992) Inner City Regeneration. The Demise of Regional and Local Government. Open University Press, Philadelphia.

Perger É. (1999) Közigazgatási dilemmák. - Barta Gy.-Beluszky P. (szerk.) Társadalmi-gazdasági átalakulás a budapesti agglomerációban. Regionális Kutatási Alapítvány, Budapest. 181-222. o.

Rückwardt, B. (1978) Koordination des Verwaltungshandelns. Duncker and Humblot, Berlin.

Soós G. (2004) Helyi demokrácia a megyei jogú városokban. Eötvös Károly Közpolitikai Intézet, Budapest. http://ekint.org/tanulmanyok/hdmjv/index.html

Stoker, G. (1995) Regime Theory and urban Politics. - Judge, D.-Stoker, G.-Wolman, H. (eds.) Theories of Urban Politics. Sage, London. 54-72. o.

Stoker, G. (ed.) (2000) The New Politics of British Local Governance. Macmillan Press, New York.

Stone, C. (1989) Regime Politics: Governing Atlanta, 1946-1988. Lawrence, University Press of Kansas, Kansas.

Stone, C. (1993) Urban regimes and the capacity to govern: a political economy approach. - Journal of Urban Affairs. 15. 1-28, o.

Stone, C. (1995) Political Leadership in Urban Politics. - Judge, D.-Stoker, G.-Wolman, H. (eds.) Theories of Urban Politics. Sage, London. 96-117. o.

\section{GOVERNANCE PHILOSOPHY OF THE NEW URBAN POLICY}

\section{ILONA PÁLNÉ KOVÁCS}

The paper wishes to call the attention to the fact that the increasing role of cities - which could be experienced even in the European cohesion policy -, is in many respects absent in the domestic institutional system of regional policy and in the territorial public administration.

While cities, especially larger towns with regional and metropolitan functions become even officially the eligible recipients of the development supports their position within the system of public administration is not privileged at all.

On the other hand the spatial functions of the cities are not integrated systematically neither in the provisional system of public services at district level nor in the territorial planning.

The voluntary micro-regional associations of municipalities and the model of cities with county rank do not provide for proper solutions.

The paper implies that much more attention should be devoted to the new paradigms of city governance which were formulated for example by the urban regime theory but its adaptation in Hungary has been fulfilled just partially. 